\title{
THE PROBLEMS AND THREATS OF INNOVATIVE DEVELOPMENT OF RUSSIAN REGIONS
}

Based on the analysis of the main indicators of innovative development of the Russian Federation for 2006-2013, the most acute problems and risks impeding the transition economy of Russian regions to the innovative model are revealed. There are problems of a further narrowing of the science sector, the continued reduction of human scientific potential, extremely slow formation of innovation sector, in particular the small increase of the share of innovation active enterprises, as well as volumes of their new products. The article pays particular attention to the tasks of improving regional innovative policy aimed at creating of the conditions for the formation and expanded reproduction of full-cycle innovation, involvement the business sector in the innovation processes, and the correlation between the regions innovation and socio-economic policies.

Keywords: innovation, innovative risks, production of innovations, innovative receptivity, socio-economic transformation

Today, the catastrophic degradation of traditional sources of innovative growth is a fact for almost all Russian regions. Suffice it to say that according to the World Economic Forum (WEF), Russia on the condition of the growth innovative factors takes only the 78th place in the world. Thus, only during the period of 2008-2013 Russia passed from the 45 th to the 64th place on the ability of companies to create innovations, from the 71 st to the 76th place - on availability of high-quality local services in carrying out scientific research and the higher education, from the 98 th to the 124 th place - on the existence of the latest technologies, and from the 34th to the 90th place - on the presence of scientists and engineers. [22, 23], that means, there is a high destruction process of innovative capacity in the country.

\footnotetext{
${ }^{1}$ (c) Golova I. M. , Sukhovey A. F., 2014. Text.
}

It is necessary to understand that innovation economy is the most important stage of development of the world community caused by sharply increased opportunities of a person for production of goods, intensity of withdrawal of natural resources, scales of environment impact, and also development of information systems, automobiles and communications. This socio-economic system is one of the most relevant from all the others for the reached level of development of equipment and technologies. Also, it should be noted that the increase of globalization processes brings a competitive struggle for the right of production of almost all types of goods to the whole new level. It gains global character and takes quite hard forms because of the less dependence of the business from socio-economic problems and interests of certain regions (even very obscure if to proceed from the long-term prospects of business existence) as a result is the appeared possi- 
bility of the fast change of territorial dislocation of productions on a global scale. Therefore, today, the insistent need is the transition to the innovation economy for the countries wishing not only to increase the production potential, but at least to keep the reached level of development of manufacturing industries [10, p. 21].

Transition to the innovation economy demands the essential transformations of all the system of the socio-economic relations, valuable and psychological aims of people to create in the society the conditions for the inflow of the human capital and financial resources to the innovation sphere and actualization of the processes modernization of traditional sectors of economic activity. Thus, the main efforts have to be directed on harmonization of the general system of public life with the purposes and values of the innovation economy.

Preservation and development of scientific potential are of prime importance for building the safety development of the regions and the coun- try as a whole. The science plays a crucial role for the upbringing and education quality, and so for the development a human capacity of the country, especially its elite part that is what the country can provide to its citizens. Therefore, the scientific research are the base and a nutrient medium of innovation activity. An ability of a territory to produce its own innovations depends on a science condition, it gives the opportunity not just to consume or copy someone else's scientific and technical decisions of "the second freshness", but to make its own exclusive products, capable to win in a fight for the consumer in the conditions of the global markets. The science weakness or (as in the Russian case) immaturity of structures providing a transfer of new knowledge and technologies in economy, provokes businessmen to further decrease in expenses for the creation the own innovations and as a preferable strategy to choose to copy the technics and technologies. In particular, today, the international corporations capture

Table 1

Professional and financial security of the research activities for a number of countries - members of the WTO

\begin{tabular}{|c|c|c|c|c|}
\hline \multirow{2}{*}{ Country } & \multicolumn{2}{|c|}{ Number of researchers } & \multicolumn{2}{|c|}{$\begin{array}{l}\text { Specific expenses on research and development } \\
\text { thousand dollars of the USA on } 1 \text { researcher }\end{array}$} \\
\hline & Person & $\begin{array}{l}\text { A person per } 10 \text { thousand } \\
\text { involved in the economy }\end{array}$ & $\begin{array}{c}\text { internal expenses } \\
\text { in total }\end{array}$ & $\begin{array}{c}\text { apropriations from } \\
\text { the state budget }\end{array}$ \\
\hline Russia & 447579 & 66 & 75 & 61 \\
\hline Australia & 92379 & 85 & 206 & 53 \\
\hline Austria & 35942 & 87 & 271 & 74 \\
\hline Belgium & 38168 & 85 & 214 & 72 \\
\hline Great Britain & 235373 & 76 & 166 & 60 \\
\hline Germany & 327198 & 81 & 264 & 87 \\
\hline Denmark & 35326 & 126 & 193 & 61 \\
\hline India & 154827 & 3 & 157 & $\mathrm{n} / \mathrm{a}$ \\
\hline Ireland & 14463 & 78 & 221 & 66 \\
\hline Italy & 105846 & 43 & 229 & 112 \\
\hline Canada & 146324 & 86 & 166 & 57 \\
\hline China & 1210641 & 16 & 148 & $\mathrm{n} / \mathrm{a}$ \\
\hline Mexico & 37930 & 9 & 150 & 71 \\
\hline Netherlands & 53703 & 62 & 241 & 113 \\
\hline Norway & 26453 & 101 & 179 & 91 \\
\hline Republic of Korea & 264118 & 111 & 201 & 55 \\
\hline Singapore & 32031 & 103 & 192 & $\mathrm{n} / \mathrm{a}$ \\
\hline USA & 1412639 & 95 & 284 & 105 \\
\hline Finland & 41425 & 170 & 183 & 54 \\
\hline France & 234201 & 91 & 213 & 80 \\
\hline Czech Republic & 29228 & 56 & 142 & 54 \\
\hline Switzerland & 25142 & 56 & 419 & 122 \\
\hline Sweden & 49312 & 109 & 254 & 66 \\
\hline Japan & 656032 & 104 & 215 & 49 \\
\hline
\end{tabular}

Notes: according to the data for 2011 or the close one for which there are data.

Based on: [5, P. 346-348, 358-359, 360-363]. 
the market of the equipment for oil and gas production - one of the most investment provided fields of the Russian Federation. Today, about 15\% of the Russian oilfield service market is controled by the western hi-tech companies. Their share in seismic exploration has reached $13 \%$, in drilling $48 \%$, in geophysics $-31 \%$. [2, p. 13].

Thus, the existence of strong national science is a necessary component of wellbeing of human communities according to pragmatical interests to maintain the technological independence and defense capability of the country, restoration of manufacturing industr,y and the problem solution of employment, especially in old industrial regions (in Russia it is a considerable part of the western, central regions of the country, and also Ural).

One of the most objective indicators of the scientific sphere is the dynamics of number and age structure of the scientific staff. In comparison with 1992, in Russia the number of scientists fell by one half. It is naturally from the cultural and historical point of view. It can be expected that the strongest tectonic shifts in the Russian society caused by the death of a state based on the communist ideology, and corresponded system of managing will not tackle science and education. On the contrary, the science, education and innovative activity as elements of high culture are especially fragile. Thus, the applied sector of science, as the most depended on the environment dies away first of all (scales and possibility of its existence in many respects are defined by the structure of production and quality of the enterprise environment, readiness of business and the state to go for additional expenses and risks connected with innovative activity). The fundamental science is more self-sufficient and capable to keep rather a decent level of research for longer even at poor financing and in the condition of isolation. However, if the time of "thin cows" lasts more than 10-15 years, irreversible processes will tackle this sphere.

In Russia at the present time, there are already 66 full employment researchers per 10 thousand people involved in the economy (Table 1). If the European countries are a reference point, for the average technological development of the country is no good to have less than 70-80 researchers per 10 thousand people involved in the economy.

According to it, and considering a need of rejuvenation of the Russian science for preservation of prospects of healthy socio-economic growth of the country, it is necessary to create conditions annually attracted in the scientific sphere $4-5 \%$ of the total number of researchers or about 2025 thousand of university graduates. Meanwhile, the low salaries and high barriers in a way of career growth make the Russian science unattractive to the most active part of the youth. Now, in the scientific organizations only $1 \%$ of university graduates [5, p. 53] comes to work there, its majority (unfortunately, not the worst) are leaving the scientific research institutes within the first 3-5 years of work.

Table 2 shows that in 2006-2011 there was further very strong collapse of the staff potential of science, especially in remote regions. For this period, on the territorial subjects of the Russian Federation, the average number involved in the Research and Development (R\&D) per 10 thousand people involved in the economy decreased by $10 \%$, the maximum is $8,4 \%$, and the minimum is $61,3 \%$

It contradicts the general course of the countries orientated to innovative growth. So, in Germany for 2000-2010, despite the next world economic crisis, the number of involved in the R\&D in the equivalent of full employment increased for $12 \%$, in Brazil - for $30 \%$, in the Republic of Korea - for $41 \%$, and in China - for $70 \%$ (based on $[18$, p. 73]).

Average age of researchers in the public sector of science of the Russian Federation reached 52 years and in the enterprise -57 years [18]. The rupture of generational continuity of scientists and dying away of scholar schools is observed everywhere. As a result, the weakened in years of reforms the new knowledge and possibility of its reception within the country is destroying.

Irresponsible actions of the last years from the leaders of the country over the academic science the most remained part of national scientific potential - can finally undermine scientific forces of Russia. With loss of fundamental science, Russia will lose not only the prospects of innovative development, but also the ability to remain among the civilized states.

The interrelations between the financial results of activity of the Russian regions and the amounts of financing of science it is not visible and cannot be visible, it is caused by the raw orientation of the economy and the specifics of the financial security of scientific research in the Russian Federation. Its basis (over 70\%) is made by the financing of the federal budget and various federal funds and structures like "Skolkovo" which exist only or mainly at the expense of public funds. The share of regional budgets in public financing of science makes less than $0,1 \%$. The share of a business sector of the general financing of R\&D is only about $16 \%[11$, p. 73$]$, its essential part is investments of the enterprises with 
Table 2

Dynamics of overall index of condition of the scientific and innovative activity in the territorial subjects of the Russian Federation in 2006-2011

\begin{tabular}{|c|c|c|c|c|c|c|c|c|}
\hline Index & & 2006 & 2007 & 2008 & 2009 & 2010 & 2011 & 2011 to $2006 \%{ }^{*}$ \\
\hline \multirow{4}{*}{$\begin{array}{l}\text { Number of involved in the } \\
\text { research and study per } 10 \\
\text { thousand people }\end{array}$} & average & 63,0 & 61,8 & 58,4 & 57,5 & 56,1 & 56,7 & 90,0 \\
\hline & maximum & 400,4 & 403,3 & 374,0 & 376,1 & 377,7 & 366,7 & 91,6 \\
\hline & median & 32,0 & 36,2 & 30,5 & 29,2 & 28,3 & 31,1 & 97,2 \\
\hline & minimum & 3,1 & 2,8 & 2,3 & 0,1 & 0,4 & 1,2 & 38,7 \\
\hline \multirow{4}{*}{$\begin{array}{l}\text { Expenses for R\&D per } 10 \\
\text { thousand involved in the } \\
\text { economy, thousand rubles } \\
\text { (in the current prices) }\end{array}$} & average & 20,9 & 26,4 & 31,0 & 34,1 & 36,7 & 43,0 & 118,7 \\
\hline & maximum & 168,2 & 221,8 & 251,4 & 305,9 & 304,4 & 338,4 & 100,0 \\
\hline & median & 10,1 & 12,8 & 14,7 & 16,8 & 16,0 & 18,5 & 105,9 \\
\hline & minimum & 0,7 & 0,9 & 1,3 & 0,0 & 0,2 & 1,1 & 100,0 \\
\hline \multirow{4}{*}{$\begin{array}{l}\text { Expenses for } \mathrm{R} \& \mathrm{D} \\
\text { per } 1 \text { person involved } \\
\text { in the researches and } \\
\text { development, thousand } \\
\text { rubles (in the current } \\
\text { prices) }\end{array}$} & average & 311,4 & 412,7 & 504,2 & 537,6 & 594,0 & 682,6 & 126,6 \\
\hline & maximum & 1421,0 & 1910,4 & 1526,0 & 1429,7 & 1887,1 & 1794,7 & 72,9 \\
\hline & median & 273,8 & 364,4 & 485,0 & 503,2 & 567,7 & 670,0 & 141,3 \\
\hline & minimum & 87,4 & 100,6 & 119,4 & 138,3 & 160,6 & 130,6 & 86,3 \\
\hline \multirow{4}{*}{$\begin{array}{l}\text { Number of the granted } \\
\text { patents per } 10 \text { thousand } \\
\text { involved in the economy, } \\
\text { unit }\end{array}$} & average & 2,6 & 2,5 & 2,8 & 3,2 & 2,8 & 2,7 & 103,8 \\
\hline & maximum & 12,1 & 11,7 & 13,2 & 18,3 & 15,9 & 16,2 & 133,9 \\
\hline & median & 1,8 & 1,8 & 2,3 & 2,7 & 2,3 & 2,2 & 122,2 \\
\hline & minimum & 0,0 & 0,0 & 0,0 & 0,0 & 0,0 & 0,0 & - \\
\hline \multirow{4}{*}{$\begin{array}{l}\text { Share of the innovation- } \\
\text { active enterprises in total } \\
\text { number surveyed, } \%\end{array}$} & average & 9,0 & 8,9 & 8,6 & 8,9 & 9,2 & 9,9 & 110,0 \\
\hline & maximum & 26,1 & 23,2 & 26,9 & 33,3 & 34,3 & 33,6 & 128,7 \\
\hline & median & 8,6 & 8,9 & 8,1 & 7,9 & 8,6 & 9,2 & 107,0 \\
\hline & minimum & 0,0 & 0,0 & 0,0 & 0,0 & 0,0 & 0,8 & - \\
\hline \multirow{4}{*}{$\begin{array}{l}\text { The volume of innovative } \\
\text { products and services per } \\
10 \text { thousand involved in } \\
\text { the economy, thousand } \\
\text { rubles (in the current } \\
\text { prices) }\end{array}$} & average & 76,2 & 75,7 & 122,1 & 100,1 & 136,9 & 201,7 & 152,8 \\
\hline & maximum & 813,6 & 810,7 & 894,2 & 845,5 & 890,5 & 1232,5 & 87,5 \\
\hline & median & 33,7 & 33,9 & 66,3 & 61,3 & 77,6 & 117,3 & 200,9 \\
\hline & minimum & 0,0 & 0,0 & 0,0 & 0,0 & 0,0 & 0,0 & - \\
\hline \multirow{4}{*}{$\begin{array}{l}\text { Expenses for the } \\
\text { technological innovations, } \\
\text { thousand rubles per } 10 \\
\text { thousand involved in the } \\
\text { economy, thousand rubles } \\
\text { (in the current prices) }\end{array}$} & average & 24,7 & 27,4 & 37,8 & 44,8 & 50,9 & 74,3 & 173,7 \\
\hline & maximum & 192,6 & 206,1 & 207,8 & 469,9 & 484,8 & 624,1 & 187,1 \\
\hline & median & 14,1 & 18,4 & 22,4 & 24,4 & 29,1 & 38,2 & 156,7 \\
\hline & minimum & 0,0 & 0,0 & 0,0 & 0,0 & 0,0 & 0,0 & - \\
\hline
\end{tabular}

Notes: ${ }^{*}$ - change of finance indexation in comparison with 2006 is given in constant prices.

Based on the annual statistical book of Rosstat "Regions of Russia. Socio-economic indexes" [16].

the participation of the state. Whereas in the majority of the WTO member countries, the private business is one of the main sources of science existence. Over $40 \%$ of the total funding of the scientific research are the funds of business sector, in the USA, it is $61,6 \%$, Germany - $66,1 \%$, China $71,7 \%$ [18].

High centralization of financing and dependence on the federal budget predetermine the disposition of funds to carrying out the R\&D according to the centers, which have developed in the pre reform period of concentration of scientific staff. Moscow and St. Petersburg take the first place in the internal costs for R\&D per 10 thousand employees (they take the 5 th and 9th places among the regions of the Russian Federation by balanced financial result of activity of the enterprises per 10 thousand employees). The next are the Moscow, Nizhny Novgorod and Kaluga regions (the 28th, 32nd and 36th places in the balanced financial result of the enterprises' activity per 10 thousand employees). KhantyMansi Autonomous Okrug is the leader in financial results among the regions of the Russian Federation, in the unit costs for $R \& D$, it takes only 42 place. 
The analysis of data shows strong discrimination of the distant regions in the disposition of funds for the scientific research. If the maximum value of expenses for $R \& D$ for 1 researcher is 1,8 mln rub. per year in the regions of the Russian Federation, a median is only 670 thousand rubles in a year (tab. 2). Correlation between the number of researchers and internal costs for R\&D per 10 thousand involved in the economy in the regions of the Russian Federation is absent (the coefficient of correlation is 0,23 ) that is caused by the high influence on the distribution of budgetary funds of a personal contact and corruption component.

During the period of 2006-2011, the general costs for R\&D in the Russian Federation increased by $22 \%$ due to the growth of the budgetary expenses. But it is not enough. On the total amount of the budgetary appropriations on science, Russia remain behind the USA by 5,5 times, Japan by 1,2 times. It is important to remember that, there is a big part of expenses are taken by enterprises. If the goal is the indicators of financial security of scientific research in developed and developing countries, Russia needs to increase the general costs of $R \& D$ at least in 2-2,5 times, including budget expenses - in 4-6 times. Otherwise, by 2020 we risk remaining without science, and so without innovations.

To change the situation, it needs to carry out the state innovative policy for formation the conditions for development and expanded reproduction of innovation cycles uniting science, study, production and consumption of innovations in the country. Thus, the new conditions and restrictions of the state regulation of trade and production applied to Russia by its participation in the WTO have to be considered.

According to the WTO ideology, the state support in the directions connected to a person's development, such as education, training and retraining of staff, and also fundamental science are determined by each country separately according to its possibilities, priorities and cannot be subject to any restrictions from other participants of the organization. Therefore, at first sight, entry to the WTO does not have any danger to the fundamental science remaining the best part of scientific capacity of Russia. Moreover, if Russia adheres to the assumed obligations, the entry into the WTO has to affect positively on the intellectual property of the economic interests of a person - founders of new development, whom Russia usually neglect. It will allow to improve the scientific and scientific and technical development, its relation concerning the creation and use including its commercial purposes, to increase the interest of researchers in registration of security documents for the development. Today according to WEF, on protection of rights for the intellectual property Russia takes the 113th place from 148 possible.

However, the problem for the Russian science is how to restore its structure but not only to improve its financing, that means to recreate applied science research, first of all, in manufacturing enterprises. To provide innovative development keeping science and production in isolation developed in the Russian Federation historically is impossible. In spite of the fact that in the West is the diverse system of the state support of socalled "open" innovations, they occupy only $5 \%$ in the large hi-tech companies, $90 \%$ are the share of the innovations created by own structures, and another $5 \%$ for the spin-off-companies [9, p. 50].

Today, in the Russian Federation are only 280 industrial organizations having research and engineering departments, where 52 thousand people work (that is about $6 \%$ of the total number of the staff involved in the research and development) $[14$, p. 355]. The departments of industrial enterprises of the Russian Federation have only $9 \%$ of internal expenses for research and development. Whereas in EU the companies carry out $65 \%$ of R\&D, in Japan $-71 \%$, and in the USA $-75 \%$ [8, p. 18], and the number of the research staff occupied in the companies is $60 \%$ of human capacity of science in the majority of the developed countries [7, p. 62].

Meanwhile, the economic measures of the state support of applied research are specific according to the classification stated in the Agreement of the WTO on subsidies and countervailing measures [19], that implies rigid restrictions on the possibilities of the state stimulation of reconstruction of applied science research in the Russian Federation according to the market economy forms. According to the article of 8.2 of the WTO Agreement, the subsidies to support applied research cannot be restricted when the help for a research carried out by business, higher educational institutions, and the scientific organizations covers no more than $75 \%$ of cost of industrial research or $50 \%$ of the cost of development at pre-competition stage according to each specific project. Moreover, the public funds can be allocated only for covering the made expenses as a result of research activity (salary for researchers, the purchase of the scientific equipment, etc.). These conditions can be followed by the countries, which have achieved a high level of the private capital involvement in the innovative activity before their WTO entry. For Russia, where innovative activity of the business sector is pain- 
fully low, and where is no innovative system, this restriction can become an absolute obstacle in a way to exit from an institutional trap of low-technological effectiveness if we literally adhere to the text of the Agreement.

The specific character of the processes in the innovation sphere of the Russian Federation, and the phenomenon of heavy growth of innovative activity against the developing world economic crisis in recent years, are defined by the raw orientation of the economy. In 2006-2011, the release of innovative products, per 10 thousand people involved in the economy, increased almost by $40 \%$ across the Russian Federation (Table 2). However, this increase gain occurred due to the enterprises of materials sector, which have to update its production base against the background of increased competition in the world markets, and also a number of the resource-focused territories where are no conditions for hi-tech productions (The Tyumen North, border regions of the Far East, etc.). It should be noted that in these regions the growth of innovative activity was mostly virtual. Most likely (that the analysis of transformations of the structure of these regions' production indirectly confirms), there were not innovations, but the traditional types of raw materials and products of primary processing made with the use of new technologies well-known in the world but not applied in the region's enterprises were called the innovations in the statistical report (for example, technologies of gas liquefaction for its transportation by sea). Such substitutions of the meanings are not a rare case in the resource-extraction regions.

For the same period, there was almost the double increase of the specific costs of technological innovations (also in constant prices). But the growth occurred not in the hi-tech sectors of the economy, but in the low-tech and medium-tech manufactures of low level - extracting, metallurgical productions, coke-and petrochemistry (Table 3). For the period of 2006-2011, in the Russian Federation's processing manufactures, the expense for innovations, in constant prices, increased by $42 \%$, on production of coke and oil products - almost by 5 times, and in metallurgy by twice. That allowed to modernize to some extent these fields.

At the same time, the world economic crisis provoked the new wave of destruction of the innovative capacity of the knowledge-intensive enterprises of the country. In particular, it observes in such key directions, which are important for the problem solution of the introductions of innovations to the industrial complex of the coun- try and ensuring its technological independence that are car and equipment productions, and production of electric equipment, electronic and optical equipment; the expenses for innovations in the constant price decreased by $16 \%$ and almost by $1 / 4$ respectively (Table 3 ). As a result, there is an increase of depressive processes in the majority of the regions, the traditional leaders of the Russian Federation on development of hi-tech productions. So, in the Samara region, the release of innovative products per 10 thousand employees decreased in the constant price approximately by $12 \%$ in comparison with 2006, in Perm Krai by $33 \%$, and in the Sverdlovsk region by $40 \%$.

As the result, the sectoral structure of innovative activity becomes more and more unattractive. For instance, in 2006, the expanses for the productions of coke and oil products were about $5,1 \%$ of the general costs for the innovations in the country, and for metallurgy and production of finished metal products $-14,6 \%$. In 2011 they were already $18,3 \%$ and $19,8 \%$ respectively. Moreover, by 2011 expenses for innovations in the insignificant share of the car manufacturing and the equipment reduced by $2,5 \%$ (Table 3 ). Washing away of the hi-tech enterprises and the medium-tech ones of the high level essentially reduces the general capacity of the regions of the Russian Federation regarding the creation of the essentially new products and technologies for a long time, as their low speed of restoration of manufacturing activity and the world competition. The stronger the sector of low-technology manufacturing, the stronger orientation of the regions of the Russian Federation to loan innovations of "second-grade-fresh." As a result, the country lose the ability to create "breakthrough" innovations and perceive essentially new technological decisions.

In spite of such rapid growth of investment in the innovation sector, the share of new merchandise market, works and services increased from $0,5 \%$ in 2006 to only $0,8 \%$. The total volume of shipped product increased from $0,5 \%$ in 2006 to only $0,8 \%$. The economic indicator for new companies is the following: from $2,2 \%$ to $3,3 \%$. At such rate, Russia can not leave a chance for manufacturing industry restoration. Today in Germany the share of new product line is $3,3 \%$ of the total amount of the shipped one to France $-6,9 \%$, Great Britain $-2.0 \%$, Sweden $-5,1 \%$, and new to the enterprise, but not new to firm $-14,4 \%, 6,4 \%$, $5,3 \%$ and $4,0 \%$ respectively.

The reason, first of all, is that: today the knowledge-intensive industries were forced out to the low-profitable category. This situation happened because of shortfall industrial policy of the coun- 
Expenditures for technological innovations and RF on types of prodiction

\begin{tabular}{|c|c|c|c|c|c|}
\hline \multirow{3}{*}{ Types of production } & \multicolumn{3}{|c|}{$\begin{array}{l}\text { Expenditures for technological innovations } \\
\qquad \text { in } 2011\end{array}$} & \multirow{2}{*}{\multicolumn{2}{|c|}{$\begin{array}{c}\text { Structure of } \\
\text { expenses for } \\
\text { technological } \\
\text { innovations, \% }\end{array}$}} \\
\hline & \multirow{2}{*}{$\begin{array}{l}\text { Total, mln } \\
\text { rub. }\end{array}$} & \multirow{2}{*}{$\begin{array}{l}\text { in } \% \text { to } 2006 \\
\text { (in constant } \\
\text { costs) }\end{array}$} & \multirow{2}{*}{$\begin{array}{l}\text { per } 1 \text { employee, } \\
\text { one thousand } \\
\text { rub/people }\end{array}$} & & \\
\hline & & & & 2006 & 2011 \\
\hline $\begin{array}{l}\text { The mining productions, manufacturing activity, } \\
\text { production and distribution of the electric power, } \\
\text { gas and water, everything }\end{array}$ & 469442,2 & 143,8 & 44,6 & 100,0 & 100,0 \\
\hline \multicolumn{6}{|l|}{ Including: } \\
\hline Mining operations & 70239,3 & 151,0 & 76,6 & 14,2 & 15,0 \\
\hline \multicolumn{6}{|l|}{ including: } \\
\hline — mining of fossil fuels & 65836,2 & 155,4 & 111,9 & 13,0 & 14,0 \\
\hline Manufacturing activity & 370006,0 & 142,2 & 47,6 & 79,7 & 78,8 \\
\hline \multicolumn{6}{|l|}{ where: } \\
\hline - food production & 12562,9 & 65,6 & 9,7 & 5,9 & 2,7 \\
\hline $\begin{array}{l}\text { - pulp-and-paper production; publishing and } \\
\text { printing activity }\end{array}$ & 8493,4 & 82,1 & 23,7 & 3,2 & 1,8 \\
\hline - production of coke and oil products & 85891,6 & 486,0 & 806,5 & 5,4 & 18,3 \\
\hline - chemical production & 30738,7 & 68,1 & 73,9 & 13,8 & 6,5 \\
\hline - production of rubber and plastic products & 7793,0 & 149,7 & 31,2 & 1,6 & 1,7 \\
\hline $\begin{array}{l}\text { - metallurgical production and production of } \\
\text { finished metal products }\end{array}$ & 92942,6 & 195,0 & 93,1 & 14,6 & 19,8 \\
\hline - production of mashines and equipment & 11740,9 & 83,5 & 14,0 & 4,3 & 2,5 \\
\hline $\begin{array}{l}\text { - production of electric equipment, electronic } \\
\text { equipment, and optical equipment }\end{array}$ & 27293,6 & 76,2 & 35,4 & 11,0 & 5,8 \\
\hline — production of vehicles and equipment & 41293,3 & 97,7 & 40,0 & 12,9 & 8,8 \\
\hline $\begin{array}{l}\text { Production and distribution of electric power, } \\
\text { gas, and water }\end{array}$ & 29196,9 & 147,6 & 15,8 & 6,1 & 6,2 \\
\hline
\end{tabular}

Based on the annual statistical book of Rosstat "Regions of Russia. Socio-economic indexes".

try leaders. Therefore, the balanced financial result counting on one worker is only $2 \%$ (car production and equipment). Electro - electronic and optical equipment production is $1,9 \%$ of value of this indicator for productions, which is busy with fuel production and energy minerals.

In Russia, according to Table 3, the costs of innovations (counting on one worker, taken in cars and equipment productions) are nearly 60 times lower today, than in the productions focused on oil processing. In the cars and equipment production area, the specific weight of the organizations, which are carrying out technological innovations, is less than $20 \%$. This economic indicator is nearly in 5 times lower, than in Germany and more than 4 times lower, than in France. Radical innovations, especially basic, cannot simply be realized in such situation.

Observed revival of innovative activity is obviously not enough for a change of tendencies of degradation of scientific and production com- plexes of the country. According to A. Aganbegyan, the solution of modernization social problems of production in Russia requires additional increase in investments at technical updating at 70 billion dollars annually within the next $5-7$ years and 70 more billion dollars - on reorganization of structure of the industry, the innovative sphere and export. If we accept that at least $15-20 \%$ of these investments have an innovative focus, annual costs of technological innovations should be increased not less than by 3-4 times. Actually considering long-term technological backwardness, the share of innovations in the general expenses for modernization, especially at the first stages of its carrying out, has to be significantly more.

Thus, the main efforts should be directed to restoration of competitiveness of countries' production base (mechanical engineering, and development of productions of new technological ways). Otherwise, the hi-tech companies and the governments of other countries will successfully 
block single breaks of domestic innovators to the world markets.

For the purpose of innovative prospect's preservation, the state should decrease taxes and obligatory assignments. In addition, they should increase legislative possibilities of expenses' compensation and risks for the companies. Russia was able to do it before accession to WTO. Today there can be restrictions for such actions. This situation, of course, is difficult, but can be solved in the presence of political will

One of necessary precondition for formation and development an innovative economy in the Russian Federation is formation of the effective innovative infrastructure, promoting updating of scientific, technical and innovative capacity of the territories. It will help to accelerate a transfer of technologies and ensuring socioeconomic growth. Russia, as well as many other countries, is rather actively joined in process of creation of innovative complexes. For the beginning of 2014 about 1200 objects of innovative infrastructure, including 166 science and technology parks [12] were in the Russian Federation. However, despite of a set and a variety of these objects, it is impossible today to speak about their essential influence on activation of innovative processes. For example, in recent years in the specific weight of innovatively active enterprises was only $8 \%$ of total amount of the enterprises, and a share of the shipped innovative goods in the total amount of shipped production was about $10-12 \%$ [17. page 81]. It does not exceed averages across Russia of values of these indicators, which are normal for traditional sectors of economy.

The Russian innovative complexes do not promote the solution of such problems, as production decentralization, and alignment of disproportions of regions on level of social and economic development as it occurs in Japan, the USA and other countries. On the contrary, it increases interregional distinctions and contradictions in such important social and economic parameters, as the volumes of investment, level of the income and a population standard of living, creation of highly paid workplaces and others. Therefore, nearly $2 / 5$ all objects of innovative infrastructure fall to the share of Central federal district now.

Inefficiency of an expenditure of funds allocated for innovative development is also an important problem. Financing of separate innovative infrastructure objects is actual for Russia. This situation we can see in Skolkovo (the innovation center). It is financed in the separate line and thus by 2013 the amounts of financing of this innovation center was about 20 billion rubles. This indicator exceeded a share of financial expenses for all technology development zones and more than by 6 times - expenses on science cities for the same period [21].The inconsistency of innovation policy slows down innovative development of the Russian Federation; the policy changes its priorities regularly rushing to support new projects and forgetting about those objects and directions, which were planned to be realized yesterday. At the beginning and at the middle of the 90th, Russia "got over" the scientific and technological parks, which faded without the financial support from the state. In the late 90th - the beginning of the 2000th, there was a new hobby for science cities. However, by 2005 their development program was almost closed. Today, Russia once again tries to copy the next world trend - the idea of formation of innovative clusters. The idea itself deserves attention, for the first time it was formulated in the 90th by Michael Porter [13]. Clusters promote strengthening of positive synergetic effects of regional agglomerations, strengthen relations between science and production, and stimulate development of the real sector and development of the new markets.

Today, the Government of the Russian Federation approved list of clusters including 25 innovative clusters in the territories with a high level of concentration of scientific and technical and production activity [15]. They include a number of science cities, special economic zones and the closed territorial units and etc. The total amount of subsidies to the subjects of Federation on program implementation clusters' development for the period from 2007 until 2013 is 1.3 trillion rub., that is quite an impressive sum [6], i.e. about 200 billion rubles annually. At such financing, (expenses on R\&D carried out by participants of clusters is about $43 \%$ in a total amount of the corresponding expenses on the economy) it would be logical to expect considerable activation of innovative processes. However, according to the above presented analysis, it did not occur, though since the beginning of the campaign of the development of innovative clusters has passed more than 7 years.

There are a few reasons for it: lack of legislatively fixed status of innovative clusters, and so unclarity of how to classify economic entities, unclear mechanism of financial disposition allocated for clusters' development. Lack of the unite strategy and priorities of their development is another reason of their low efficiency. Investigation of the list of the projects of clusters' development selected for realization shows that there is still a lack of research of technologi- 
cal potential available in certain regions and real requirements of territorial industrial complexes. There are doubts in the expediency of specialization and territorial placement of a number of clusters. So, among the clusters listed at governmental website, 6 are focused on production of biopharmacology products, 3 is supposed to be created in the Siberian federal district (in the Altai region, the Novosibirsk and Tomsk regions). At the same time, special concern is caused by that fact that innovative opportunities of clusters and many other objects of innovative infrastructure are insufficiently considered at problem solving of the crucial goals for Russia and its regions such as modernization of key fields of the economy: the machine-building, metallurgical and chemical complexes. Among the mentioned list of innovative clusters only 5 are focused directly on the modernization of these complexes: two ship-building clusters in the Arkhangelsk region and Khabarovsk territory, industrial cluster in the field of motor-car construction and petrochemistry in the Nizhny Novgorod region, petrochemical territorial cluster in Bashkortostan, titanic cluster in the Sverdlovsk region. Thus, in the Russian Federation there are unsystematic and therefore, chaotic, and ineffective development of innovative infrastructure, taking essential funds from the state budget, but not bringing results.

We assume that one of the most critical goals of the modern strategic development of the Russian Federation is to connect together socio-economic and innovation processes. Until then, the innovative activity and the socio-economic sphere will develop without strengthening and complement each other, but almost autonomous. The result of their parallel development will be the increase of the technological weakness of the Russian economy, its dependence on the developed countries and further status decrease of the Russian Federation in the world community.
It is known, that the necessary conditions of essential inflow of private investments into the financing of scientific research and creation of innovations are a certain public stability, i.e. the private property security and business freedom, and also improvement of processing economic sector, first of all, mechanical engineering, and the accelerated development of the knowledge-intensive productions.

It should not be left unnoticed, that technologies in mechanical engineering and metallurgy focused on civil productions are not consisted in the list of 44 critical technologies of the Russian Federation [15]. Possibly, the experts of the list were focused on the directions of science, equipment, and technologies being the priority for the economically developed countries. However, these countries rather successfully solved a problem of modernization of the basic productions in the 6080th of XX century, whereas in Russia, this is a relevant issue.

In the Russia Federation, the innovation processes are not developed because of the undeveloped legal base in the sphere of innovative activity. In the current legislation, there are no clear purposes, prospects, priorities, and stages of innovative and technological development.

One more serious risk factor, as it was already noted, is unreadiness of scientific and hitech complexes of Russia to the WTO entry. At the same time, based on the experience of other countries, in particular China and Brazil, it is possible to solve the problems of the science development and increase the innovative activity of the national enterprises using the open markets, as well. It require a political will and understanding of the necessity of the innovation paradigm to safe production processes and national independence of the country at the globalization and in the new conditions. Especially, Russia still has the necessary human and investment resources to carry out the innovative reforms.

The article is supported by Russian Humanitarian Scientific Fund, project 14-02-00331 "Innovative and technological development of a region: assessment, forecasting and ways of achievements".

\section{References}

1. Aganbegyan A. (2011). O modernizatsii obshchestvennogo proizvodstva v Rossii [On modernization of a social production in Russia]. Kontseptsiya [Concepts], 1-2, 60-78.

2. Andryushkevich O. A., Denisova I. M. (2012). Sovremennoye sostoyanie natsionalnykh innovatsionnykh sistem [Current state of national innovative systems]. Analiz i modelirovanie ekonomicheskikh protsessov: sb. stat. [Analysis and modeling of economic processes: collection of articles], Moscow, Central Economic Mathematical Institute of the Russian Academy of Sciences, Issue 9 , 7- 30.

3. Golova I. M. (2012). Problemy formirovaniya innovatsionno-tekhnologicheskogo imidzha rossiyskikh regionov [Problems of formation of innovative and technological image of the Russian regions]. Ekonomika regiona [Economy of Region], 2, $105-115$.

4. Indikatory innovatsionnoy deyatelnosti 2013: stat. sb. [Indicators of innovative activity. 2013: collection of articles], Moscow, National Research University Higher School of Economics, 472. 
5. Indikatory nauki 2013: stat. sb. [Science indicators. 2013: collection of articles], Moscow, National Research University Higher School of Economics, 400.

6. Innovatsii $v$ Rossii [Innovations in Russia] Available at: //http://innovation.gov.ru (date of access: 23.01.2014).

7. Dynkin A. A. (Ed.). Ivanova N. I. (Ed.) (2004). Innovatsionnaya ekonomika [Innovative economy]. Moscow. Nauka.

8. Gorelyad V. P. (Ed.) Innovatsionnyy put razvitiya dlya novoy Rossii [Innovative way of development for new Russia]. Moscow, Nauka, 343.

9. Karpov A. (2012). Inzhiniringovaya platforma dlya transfera tekhnologiy [Engineering platform for a transfer of technologies]. Voprosy ekonomiki [Questions of Economy], 7, 47-65.

10. Kuklin A. A., Chereshnev V. A. (Ed.), Tatarkin A. I. (Ed.), Fyodorov M.V. (Ed.) (2012). Innovatsionnoye razvitie kak osnova ekonomicheskogo rosta ekonomiki regiona [Innovative development as a basis of economic growth of economy of a region]. Ekonomicheskaya bezopasnost Rossii. Uroki krizisa I perspektivy rosta [Economic security of Russia. Lessons of crisis and growth prospect]. Vol.1., Yekaterinburg, Institue of Economics, the Ural Branch of the Russian Academy of Sciences, 20-31.

11. Nauka Rossii v tsifrakh 2011: stat. sb. [Science of Russia in figures: collection of articles], Moscow, Centre for Science Research and Statistics.

12. Natsionalnyy tsentr po monitoringu innovatsionnoy infrastruktury nauchno-tekhnologicheskoy deyatelnosti i regionalnykh innovatsionnykh sistem [National center for monitoring of innovative infrastructure of scientific and technical activity and regional innovative systems]. Available at: http://www.miiris.ru (date of access: 22.02.2014).

13. Porter M. (1993). Mezhdunarodnaya konkurentsiya. Konkurentnyye preimushchestva stran [International competition. Competitive advantages of the countries.]. Moscow. International relations.

14. Promyshlennost Rossii. 2012: stat. sb [Industry of Russia. 2012: collection of articles]. (2012). Rosstat, Moscow, 445.

15. Rasporyazhenie Pravitelstva RF "Perechen tekhnologiy imeyushchikh vazhnoye sotsialno-ekonomicheskoye znachenie ili vazhnoye znacheniye dlya oborony strany i bezopasnosti gosudarstva (kriticheskikh tekhnologiy)” № 1273-r ot 14.07.2012 (v red. rasporyazheniya Pravitelstva RF № 1059-r ot 24.06.2013) [Order of the Government of the Russian Federation "List of technologies having important socio-economic value or importance for defense of the country and safety of the state (critical technologies)" No. 1273-r of 14.07.2012 (in an edition of the order of the Government of the Russian Federation No. 1059-r of 24.06.2013)].

16. Regiona Rossii. Sotsialno-ekonomicheskie pokazateli. 2012: stat. sb. [Regions of Russia. Socio-economic indexes. 2012: collection of articles]. (2012). Rosstat, Moscow, 990.

17. Gokhberg L. M. (2011). Rossiyskiy innovatsionnyy indeks [The Russian innovation index]. Moscow. Vysshaya shkola ekonomiki [Higher School of Economics].

18. Rossiya i strany mira. 2012: stat. sb. [Russia and world countries. 2012: collection of articles]. Rosstat. Moscow. 2012.

19. Soglashenie po subsidiyam i kompensatsionnym meram [The agreement on subsidies and countervailing measures]. Available at: http://www.wto.ru/documents.asp? $\mathrm{f}=\operatorname{sog} \& \mathrm{t}=13$ (date of access: 15.06.2013).

20. Sukhovey A.F., Golova I.M. (2011). Regionalnyye sistemy sozdaniya i peredachi tekhnologiy [Regional systems of creation and transfer of technologies]. Yekaterinburg, Institue of Economics, the Ural Branch of the Russian Academy of Sciences, 52.

21. Untura G. A. (2011). Territoriya innovatsiy: rasshirenie spektra vozmozhnostey [Territories of innovations: expansion of a range of opportunities]. EKO, 11.

22. The Global Competitiveness Report 2008-2009. World Economic Forum. Available at: http://www.weforum.org/gcr (date of access: 15.01.2014).

23. The Global Competitiveness Report 2013-2014. World Economic Forum. Available at: http://www.weforum.org/gcr (date of access: 15.01.2014).

\section{Information about the authors}

Golova Irina Markovna (Yekaterinburg, Russia) - Doctor of Economics, Senior Researcher at the Sector of Social Innovation, Institute of Economics of the Ural Branch of the Russian Academy of Sciences (29 Moskovskaya str., Yekaterinburg, 620014, Russia, e-mail: irina_golova@mail.ru).

Sukhovey Alla Filippovna (Yekaterinburg, Russia) - Doctor of Philosophical Sciences, Professor, Head of the Sector of Social Innovation, Institute of Economics of the Ural Branch of the Russian Academy of Sciences (29 Moskovskaya str., Yekaterinburg, 620014, Russia, e-mail: alla_suhovey@list.ru). 